\title{
Does the Sermon on the Mount include an ecological message?
}

A contribution to an ecological spirituality

Marian Machinek* marian.machinek@gmail.com https://orcid.org/0000-0002-1857-1018 https://doi.org/10.31192/np.18.3.12

UDK / UDC: $27-247.4$

[574:2-188]:27-273

Izvorni znanstveni rad / Original scientific paper Primljeno / Received: 27. srpnja 2020. / Jul 27, 2020 Prihvaćeno / Accepted: 4. rujna 2020. / Sep 4, 2020

The purpose of this article is to examine whether the Sermon on the Mount (Matt 5-7) can be an inspiration for ecological spirituality. Jesus' diagnosis of the human attitude (Matt 6:19-34), marked by an immoderate desire to possess and by excessive concern for the future, has not lost anything in its relevance. Changing this attitude might be possible through a renewed look at surrounding nature. The relationship to God will be a key element of Christian ecological spirituality.

Keywords: anthropocentrism, desire to possess, ecology, ecological spirituality, existential anxiety, Father in heaven, Gospel of Matthew, Sermon on the Mount.

\section{Introduction}

The Gospel according to Matthew contains a remarkable passage, which since the time of St. Augustine has been referred to as the Sermon on the Mount. ${ }^{1}$ This unique compilation of Jesus' words comprising chapters 5, 6 and 7 of the Gospel of Matthew has influenced believers (and not infrequently also unbelievers!) down the centuries so deeply that the history of its reading and interpretation coincides almost with the entire history of Christian spirituality. The question arises if in the context of ecological issues this part of the Matthew Gospel can also provide an impetus to revise the attitude to the surrounding world? The Sermon on the Mount is not, of course, a text concerning, in

\footnotetext{
* Marian Machinek, PhD, Full Prof., University of Warmia and Mazury in Olsztyn; Address: Ul. Hozjusza 15, PL-11-041 Olsztyn, Poland.

1 AUGUSTINE, De Sermone Domini in Monte, PL 34, 1229-1307.
} 
the first place, ecological issues. But in the light of environmental discussions some passages of the Sermon of the Mount assume the nature of »intimations of ecological theology . $^{2}$

Although the main source for these considerations will be biblical comments, the aim of this article is not an exegetical-biblical analysis of some excerpts of the Sermon on the Mount. Rather, it is about examining which of the many spiritual and ethical impulses in which the Sermon on the Mountain abounds can be helpful in developing an ecological spirituality. Pope Francis emphasizes this in his encyclical Laudato Si. Without such a form of spirituality, as the Pope states, it will not be possible to achieve an »ecological conversion «, which is an indispensable condition for a renewed human relationship to the surrounding world. ${ }^{3}$ In search of inspiration for an ecological spirituality, apart from the motif of the relationship to the Father in heaven, the components of the Sermon on the Mount seem to be interrelated, where Jesus speaks of lasting and transitory goods (Matt 6:19-24) and about unnecessary worries (Matt 6:25-34. These two sections along with other particular motifs of the Sermon on the Mount form the basis for this paper.

\section{The roots of the ecological crisis}

The whole Sermon on the Mount is an instruction concerning the proper attitude of the disciple, ${ }^{4}$ the person who has received the Good News of the coming kingdom of God and seeks to live it. In the two excerpts mentioned above, Jesus points to attitudes contrary to His message, which can now be identified as the profound causes of the ecological crisis. This kind of attitude begins in individuals and eventually leads to widespread mentality and the creation of social and economic structures devastating the environment.

\subsection{The longing to possess}

The first excerpt is a warning against the seducing power of wealth:

»Do not store up for yourselves treasures on earth, where moth and rust consume and where thieves break in and steal; but store up for yourselves treasures in heaven, where neither moth nor rust consumes and where thieves do not

${ }^{2}$ Cf. Russel PREGEANT, Knowing Truth, Doing Good. Engaging New Testament Ethics, Minneapolis, MN, Fortress, 2008, 139.

${ }^{3}$ FRANCIS, Laudato Si' (Mai 24, 2017), 203; http://w2.vatican.va/content/francesco/en/encyclicals/documents/papa-francesco_20150524_enciclica-laudato-si.html (27.07.2020). Hereafter cited as LS.

${ }^{4}$ Cf. Gerhard LOHFINK, Wem gilt die Bergpredigt? Zur Glaubwürdigkeit des Christlichen, Freiburg, Herder, 1988, 36-38. 
break in and steal. For where your treasure is, there your heart will be also « (Matt 6:19-21 NRSV, used throughout).

Speaking of the desire to gather treasures on earth, Jesus points to an extremely destructive attitude, which is an exaggerated desire to possess. A deeper analysis of Jesus' words indicates that it is not the mere possession and collection of goods as such which is so negatively described here. The focus of attention is rather the way in which a person refers to their possessions. The tendency to accumulate goods is something inherent in human nature and can be described as natural, characterizing any healthy personality. This human propensity to gather wealth does not seem to be a problem for Jesus, but rather it is the motivation and above all how and with what attitude that it is done which is His concern. At the heart of this passage is the key distinction between permanent and non-permanent treasures. There are impermanent goods, the transience of which Jesus illustrates with images of destruction, whether due to pests, weather conditions, or finally the destructive activity of other people. In the text the word thesauros is used, which means treasure, such as gold or silver coins in caskets. Such a treasure may be stolen, but it will no longer become a target of moths or rust, as Jesus mentions. It seems, therefore, that the addressees of Jesus' warnings are not merely very rich people, but anyone who owns valuable things and gathers goods. Jesus warns of concentrating excessively on the accumulation of such treasures. However, it is not just that this activity will turn out fruitless, but more that insofar as it absorbs human energy it distracts one from much more important matters, and can even enslave one. Then the person is no longer able to turn to what is truly worthy, or to God and His reign. The kind of treasure that someone pays attention to »determines an individual's existential orientation ${ }^{5}{ }^{5}$

It is not only the type of treasures that one accumulates but also the purpose that one guides which is important here. Therefore, the opposite of gathering treasure in heaven would be simply to gather treasures on earth but gathering it solely for oneself. The source of such an attitude is deep-rooted egocentrism. ${ }^{6}$ The possession of transient goods and the desire to increase them must be controlled, otherwise it may become a destructive tendency, encompassing human consciousness and subordinating all human abilities, desires, and longings. While »to have« is something normal for everyone, an unlimited greed »to have more « can not only twist the personality and ultimately annihilate human life, but also harm the environment.

»For where your treasure is, there your heart will be also « (Matt 6:21), says Jesus. This final sentence of Jesus from this passage of the Sermon on the

${ }^{5}$ Georg STRECKER, The Sermon on the Mount. An Exegetical Commentary, Edinburgh, T\&T Clark, 1985, 132.

${ }^{6}$ Carl G. VAUGHT, Sermon on the Mount. A Theological Interpretation, Waco, TX, Baylor, 2001, 141-142. 
Mount reflects the daily experience of the true values which someone confesses: in everyday life thoughts revolve around what a person considers truly valuable and what they strive for. Time and available funds are invested in what is considered valuable. »Nothing enslaves more than that which we think we cannot live without. To be so enslaved, moreover, is to be captured by the powers of this world «. ${ }^{7}$ Whoever wholly dedicates themselves to the accumulation of worldly goods will eventually become dependent on them. This dependence is so deep that it becomes the cause of a particular kind of blindness that provokes addiction.

How far the right view of the world can be disturbed, is illustrated by a somewhat strange parable about the lamp (light) for the body:

»The eye is the lamp of the body. So, if your eye is healthy, your whole body will be full of light; but if your eye is unhealthy, your whole body will be full of darkness. If then the light in you is darkness, how great is the darkness!" (Matt 6:22-23). ${ }^{8}$

One can reject God's light to the extent that he will mistakenly consider darkness as light, and is convinced that he is appropriately judging reality. Such a false conviction makes the darkness inside a person even deeper.

The profundity of this blindness Jesus calls a service of wealth: »No one can serve two masters; for a slave will either hate the one and love the other, or be devoted to the one and despise the other. You cannot serve God and wealth" (Matt 6:24). The word mamonnas used here, which is today associated with wealth and money, had a much broader meaning in Jesus' words. Originally, the word meant a support or refuge, and so everything on which life could be based, and it had a rather neutral tone. However, it later acquired a pejorative meaning as an »unjust mammon «?. And it is in this sense that Jesus seems to use this word. The service of mammon means that someone concentrates so much on possessions that there is no room left in their life for God. ${ }^{10}$ Jesus compares such a crooked relationship to earthly goods to entering into service to them. For Jesus' listeners, the servant was not simply an employee who contracted with his employer for a certain payment for a certain period of work. It was rather someone who was boundlessly devoted to his master and, without

\footnotetext{
7 Stanley HAUERWAS, Matthew (Brazos Theological Commentary on the Bible), Grand Rapids, Brazos, 2008, 80.

${ }^{8}$ Cf. Hans Dieter BETZ, Essays on the Sermon on the Mount, trans. Larry L. Welborn, Philadelphia Fortress, 1985, 71-87.

9 Joachim GNILKA, Das Matthäusevangelium, vol. 1 (Herders Theologisches Kommentar zum Neuen Testament, Freiburg im Breisgau, Herder, 1986, 243.

${ }^{10}$ Craig A. EVANS, Matthew, Cambridge, Cambridge University Press, 2012, 302-305; John NOLAND, The Gospel of Matthew, Eerdmans, Grand Rapids MI, 2005, 303-304. Cf. Carter WARREN, Matthew and the Margins: A Sociopolitical and Religious Reading (Bible and Liberation Series), New York, Orbis, 2001, 173-176.
} 
objection, carried out his orders. ${ }^{11}$ In fact simply a slave, as indicated by the similarity between the verb douleuo - to serve and the noun doulos - slave.

Jesus' analysis of the attitude to one's possessions has not lost any of its relevance today. It would be difficult not to notice this attitude in many modern people, as much as in the structures that they build. Such attitudes are based, on the one hand, on the myth of unlimited progress, governed by the laws of supply and demand, which cannot be stopped or directed. On the other hand, the people who build this kind of structure are guided by the blind belief that progress alone will provide the ways and means to solve the problems it has created. This is a passive attitude based on the conviction that dramatic consequences for the environment are inevitable, as progress cannot be stopped and the only thing that is considered possible is to minimize the negative impact on the environment, rather than change anything in the way of life and conduct.

\subsection{Anxiety}

The second motif from the Sermon on the Mount, which can be identified as a root of the contemporary ecological crisis, is the particular kind of existential anxiety which is associated with the obsessive accumulation of goods. Jesus describes this attitude in another long passage of his speech concerning the worries that are unnecessary:

»Therefore I tell you, do not worry about your life, what you will eat or what you will drink, or about your body, what you will wear. Is not life more than food, and the body more than clothing? Look at the birds of the air; they neither sow nor reap nor gather into barns, and yet your heavenly Father feeds them. Are you not of more value than they? And can any of you by worrying add a single hour to your span of life? And why do you worry about clothing? Consider the lilies of the field, how they grow; they neither toil nor spin, yet I tell you, even Solomon in all his glory was not clothed like one of these. But if God so clothes the grass of the field, which is alive today and tomorrow is thrown into the oven, will he not much more clothe you-you of little faith? So do not worry, saying, 'What will we eat?' or 'What will we drink?' or 'What will we wear?' For it is the Gentiles who strive for all these things; and indeed your heavenly Father knows that you need all these things. But strive first for the kingdom of God and his righteousness, and all these things will be given to you as well. So do not worry about tomorrow, for tomorrow will bring worries of its own. Today's trouble is enough for today« (Matt 6:25-34).

In many biblical commentaries, it is precisely in relation to this passage that many critical remarks appear. It is sometimes referred to as an expression of a very naive view of reality. This naivety, as one says, is exposed, on the one

\footnotetext{
${ }^{11}$ Richard T. FRANCE, The Gospel of Matthew, Grand Rapids, MI, Eerdmans, 2007, 262; Klaus WENGST, Das Regierungsprogramm des Himmelreichs. Eine Auslegung der Bergpredigt in ihrem jüdischen Kontext, Stuttgart, Kohlhammer, 2010, 170-171.
} 
hand, in an idealistic image of nature, completely incompatible with everyday experience, and on the other hand, in the suggestion that since God cares about humans more than other living beings, one can completely stop caring about everyday life. It must be said that Jesus' call to abandon excessive concern would indeed be completely unrealistic if it is understood as a call to abandon the necessary procedures for daily functioning.

These problems have already been noticed by earlier commentators, as evidenced by Martin Luther's famous statement that God admittedly provides food for birds, but does not drop it in their beaks. ${ }^{12}$ The fact that Jesus' words are not an invitation to not do anything, to idle, to abandon all planning and all activity, is already set out in the introduction to the section of worrying. What Jesus criticizes is the fear and care born of the desire to gather transient goods. The attitude of obsessive concern is expressed here in the word merimnao, which in this passage is repeated up to six times. In earlier translations of the Bible, this word has been translated as »caring too much «. There is no condemnation in Jesus' words for every precaution: the Father in heaven knows what is needed, and therefore acknowledges that man must satisfy his fundamental material needs (Matt 6:32). ${ }^{13}$ In some dictionaries, the word merimnaō is translated as a constant consideration of the various possible outcomes of current events, focusing the attention entirely on what is to come, being torn apart between the hope of good outcomes of events and the fear of the possibility of disaster..$^{14}$ Dietrich Bonhoeffer describes in his interpretation of the Sermon on the Mount that a particular mechanism emerged under the influence of such worries: »Anxiety creates its own treasures and they, in turn, beget further care.$_{.}^{15}$ Jesus admittedly cites a common-sense argument: excessive concern for the future is of no benefit, because no one has power over what comes (v. 27). However, the main argument remains theological. The attitude of worrying is characterized by the Gentiles (ethne - »nations «), or people unconscious of the fact that there is a Father who takes upon himself every human concern. In another place in the Sermon on the Mount, namely in the teaching about prayer (Matt 6:7), Jesus describes another aspect of this attitude, namely verbosity in prayer. Such a prayer is marked by a similar concern, for its efficacy depends on the quantity of words. ${ }^{16}$ The lack of awareness of God's care creates a painful tension in the mind, resulting from the conviction that a successful future will be possible only through hectic activity in the present. Jesus wants

\footnotetext{
${ }^{12}$ Cf. France, The Gospel of Matthew...., 268.

${ }^{13}$ Craig S. KEENER, A Commentary on the Gospel of Matthew, Grand Rapids, MI, Eerdmans, 1999, 237.

${ }^{14}$ Fritz RIENECKER, Sprachlicher Schlüssel zum Neuen Testament, 18 Edition, Giessen - Basel, Brunnen, 1987, 15.

${ }^{15}$ Dietrich BONHOEFFER, The Costs of Discipleship, London, SCM, 1971, 158.

${ }^{16}$ France, The Gospel of Matthew..., 270; Ulrich LUZ, Matthew 1-7. A Commentary, Minneapolis, Fortress, 2007, 303-304.
} 
to free his disciples from this destructive tension, precisely by pointing to the presence of the Father who hears what is being asked, knows about their needs and cares for their satisfaction. Jesus, therefore, connects the excessive concern for the future with lack of faith, which occurs here as a kind of antithesis of the previously mentioned excessive concern. The word oligopistos used here by Jesus means to believe little or not enough. In Matthew's Gospel, this word appears several times (Matt 6:30; 14:31; 16:8). The problem seems to be a shaky belief in God's care, which exists in theory, but when there arises a situation of danger or tension connected to everyday existence, the place of trust is taken by obtrusive care, which begins to dominate and encompasses more and more human consciousness. ${ }^{17}$

These two attitudes: the lack of any reasonable bounded desire to accumulate goods and the dreadful fear of losing the goods which one possess, in the contemporary context intertwine in a phenomenon which Pope Francis describes as »obsessive consumerism«. As the Pope Francis emphasizes, it is a »subjective reflection of the technocratic paradigm $«{ }^{18}$ but this is not limited to an era in which technology has developed rapidly. The Gospel of Matthew and the other canonical Gospels know a number of characters who are so completely obsessed with the accumulation of goods that even a meeting with Jesus cannot change them (an example could be the passage about a rich young man - Matt 19:16-22). The manner in which to possess goods is not a new problem, and according to Jesus it is not a secondary matter at all, but determines the whole direction of life, influencing not only one's own existence but also one's relationship to one's surroundings. It is undoubtedly one of the profound causes of the ecological catastrophe to disseminate an uncontrollable desire to possess goods associated with fear for the future and to consolidate it by creating economic structures that stimulate and sustain such a lifestyle.

\section{2. »Look!«}

So what is the way out of this intertwining of the destructive attitude of desire for possession and of the excessive concern that underpins compulsive consumerism? Jesus first invites to revise the way in which one perceives the surrounding world. It would be obviously an exaggeration if one considers Jesus' mentioning of the lilies of the fields and birds in the sky in Matt 6:26-28 a special ecological motif ${ }^{19}$, but the context of this statement seems to be im-

\footnotetext{
${ }^{17}$ Keener, A Commentary on the Gospel of Matthew..., 236-237; EVANS, Matthew, 313-314; Vaught, Sermon on the Mount..., 148-150; Robert T. KENDALL, The Sermon on the Mount, Oxford, Monarch, 2013, 295-298.

${ }^{18}$ LS 203.

${ }^{19}$ John R. W. STOTT, The Birds Our Teachers, Oxford, Lion Hudson, 2007, 11-16 and 9: »It was Jesus Christ himself in the Sermon on the Mount who told us birdwatchers «.
} 
portant to the issue of ecological spirituality. Warning the disciples against excessive worrying Jesus makes them look at the world around, but the matter is not merely a statement of empirical facts.

»Creation is not just seen but seen as something. What is seen depends on how it is seen, and this, in turn, depends on presuppositions, whether acknowledged or not. Perception is always from the point of view of the perceiver «. ${ }^{20}$

Jesus refers here again to seeing properly, as before in the parable of the lamp for the body, which is the eye. The use of the word emblepo suggests not only a superficial look but a much deeper one connected with insight. It is therefore about »a searching look in order to learn $\ll{ }^{21}$ Such a look, which assumes taking a longer time and focused attention, simply means a way of approaching world. $^{22}$

A human person can see the world around them in different ways. ${ }^{23}$ Usually, the first perspective that is imposed is related to the useful aspect of the surrounding reality. This way of looking is connected with work, that is, that specifically human activity, which not only aims to achieve the intended goals but at the same time develops the working person. However, such a perspective on surrounding reality is very narrow. The dominant question is here: What can I use of the world around me? The world, including living beings, is seen here as a kind of raw material, a useful matter that can be consumed or used to achieve human goals. Humankind has constantly tried to adapt the surrounding world to its own needs and it would be difficult to blame it for doing so. The genius of the human species lies precisely in the fact it not only adapts its behavior to the surrounding reality, as other living beings do, but thanks to its rationality is able to process the surrounding reality so that it serves its own purposes. However, this kind of relationship to the world must be supplemented by other ways, not so strongly anthropocentric, by a deeper »look« at reality, going beyond the strictly useful aspect.

First of all, it is about perceiving other living beings not only as a raw material but also as particular beings, which, apart from the meaning which someone ascribes to them, have their own developmental dynamics and related requirements, and above all, their own inherent value. Humankind increasingly learns to see the world around them not just as material for processing and use, but as a wealth of living beings, connected with each other by multiple dependencies.

\footnotetext{
${ }^{20}$ Margaret BARKER, Creation. A Biblical Vision for the Environment, London, T\&T Clark, 2010, 26.

${ }^{21}$ France, The Gospel of Matthew..., 264. Cf. also Herman HENDRICKX, The Sermon on the Mount, London, Geoffrey Chapman, 1984, 144-45.

${ }^{22}$ Hans Dieter BETZ, The Sermon on the Mount. A commentary on the Sermon on the Mount, including the Sermon on the Plain (Matthew 5:3-7:27 and Luke 6:20-49), Minneapolis, MI, Fortress Press, 1995), 474.

${ }^{23}$ Cf. Eberhard SCHOCKENHOFF, Etyka życia. Podstawy $i$ nowe wyzwania, Opole, Wydział Teologiczny UO, 2014, 578-582.
} 
The more someone sees himself as an element of this world, the more he learns to properly handle other living beings. As far as one is able to look at other living beings in this deeper way, his peculiarities of living will become a kind of communication for him, informing him how other living beings should be treated. It is important to see and respect their needs so that the relationship to the world is marked by a kind of symbiosis.

In addition to those, there is another deeper way of »looking « at the world, which is associated with experiencing a dimension, which, on the one hand, can only be perceived by a human being, but is on the other hand often neglected: it is to perceive the beauty of creation. This specific way of looking could be included in the concept of contemplation. Speaking about the beauty of creation, of course, is also questionable. A naturalist will point out that colors, shapes, and behavior in the world of living beings perform specific functions and serve the survival of the species, not to delight man. Many famous naturalists pointed to a brutal struggle for survival, which did not facilitate contemplation, and rather led to a critical reflection on the goodness of the Creator. However, this does not change the fact that the richness of the colors and the multiformity of the world of living beings can delight and encourage a human person to be in a natural environment, or even to process the environment so that it becomes a source of pleasant sensations.

In the form of a paradox, Jesus brings together the beauty of creation and its transience and impermanence. Despite sometimes stunning beauty, creatures die and pass away. Jesus does not idealize nature, there is no "mysticism of nature" in His words. ${ }^{24}$ Birds eventually fall to the ground - they die (Matt 10:29), and even the most wonderful plants wither (Matt 6:30). Nevertheless, they are the object of concern to the heavenly Father, who creates the right conditions in which life is possible. Jesus also seems to assume that man uses nature for his purposes. The shriveled lilies are burned, says Jesus (probably an allusion to the widespread use of dry grass as fuel), and birds are subject to a financial transaction: »Are not two sparrows sold for a penny? (Matt 10:29).

The contemplative and holistic view of nature, to which Jesus calls in the Sermon on the Mount, undoubtedly prevents an exclusive concentration on its utilitarian aspects, which are often associated with the acquisitiveness and excessive anxiety criticized by Jesus, which lead people to become servants of mammon. Thanks to a deep and holistic view of reality, a person will be able to change his attitude. Seeing nature in its whole truth (and not just in relation to its mere useful aspects) allows man not to serve wealth in a slavish way. ${ }^{25}$ At the same time, however, this holistic view is intended to direct attention to the Creator. Such a view of the world awakens and supports faith in the care of the Creator, but at the same time, it assumes this faith. Lilies and birds are

\footnotetext{
${ }^{24}$ Eduard SCHWEIZER, The Good News according to Matthew, London, SPCK, 1976, 164-165.

${ }^{25}$ Evans, Matthew..., 301.
} 
here not a kind of model for human conduct but are intended to make human beings look at the world as a sign and expression of the power and goodness of the Creator. ${ }^{26}$ Thus, this call to look at nature opens the way to a different perspective from the previously mentioned obsessive concern for the future.

"With such a faith they can look at (6:26, and learn the lesson from; 'consider' $6: 28)$ this situation with a sound (undivided) eye. By so doing they can recognize signs of their Father's righteousness in the way in which he takes care of the needs of the birds, of the lilies and also in the way in which he makes his sun rise and sends rain $(5: 45) \ll .{ }^{27}$

It is worth paying attention to one more motif: the heavenly Father's care, both towards plants and animals, and even more so towards humans, is marked with an extraordinary abundance. This divine logic, so different from a logic purely based on calculation, is visible in the whole creation. The theme of abundance is simply one of the features of the Creator, who will play a central role in every concept of Christian ecological spirituality.

\section{Father in Heaven}

There is no doubt that the right depiction of God is the foundation of all Christian spirituality and morality. Only in its light and with it as a basis is it possible to ask about norms and commandments. This depiction of God, corrected by Jesus, will also be the focal point of a Christian ecological spirituality. This is the point which distinguishes Christian ecological spirituality from other forms of spirituality. Each form of spirituality refers to the spiritual needs of the human person, which implies both their definite concept, as well as the acceptance (or rejection) of God's existence, and particular depiction of Him. The term »spirituality« is associated with the assumption of a spiritual, extra-material dimension of existence, although today - also in the context of ecology - one tries to build forms of spirituality without reference to the Creator, or at least without reference to the personal Creator. Spirituality is then understood as, for example, a form of harmony with the universe and other living beings. ${ }^{28}$ Typically, this type of spirituality uses elements from the religious traditions of the Far East, especially those in which one puts in brackets the question of the existence of a personal God (e.g. in Buddhism). Moreover, religion and its characteristic reference to the Creator, especially in the context of the Judeo-Christian tradition, is sometimes seen as one of the

\footnotetext{
${ }^{26}$ Schockenhoff, Die Bergpredigt..., 274.

${ }^{27}$ Daniel PATTE, The Gospel According to Matthew: A Structural Commentary on Matthew's Faith, Philadelphia PA, Fortress, 1987, 95.

${ }^{28}$ There are today even forms of atheistic spirituality; Cf. André COMTE-SPONVILLE, The Little Book of Atheist Spirituality, New York, Penguin Books, 2008.
} 
main causes of the environmental crisis. Already in the 1960s the Christian religion was accused of committing an »ecological sin «. According to this view the Judeo-Christian tradition had brutally de-mythologized the cosmos and nature, thereby losing the spiritual connection with the surrounding world, which became for it simply a matter subjected to human beings. Hence, the rejection of the Creator along with subjecting the created world to the governance of human beings is seen as an indispensable condition for an adequate approach to nature and for the resolution of the ecological crisis. It is claimed that the re-mythologization of the world is essential. Humans do not constitute a unique element, but are simply one of the forms of life. According to this narrative, only thanks to such »humility«, as a result of which man does not treat himself as a unique creation, will it be possible to save the Earth from the impending ecological disaster.

It is difficult to agree with such a distorted image of the influence of the Judeo-Christian tradition on the ecological crisis. Environmental devastation occurs not only in traditionally Christian countries but also in countries where the influence of Christianity is negligible. The truth is, of course, undoubtedly, that the Judeo-Christian tradition has contributed a kind of de-mythologization of the world. The key text here, of course, is the beginning of Genesis with a double description of the creation of the world. It became a strong impetus for the development of science and technology, freeing humankind from fear of the divine forces of nature. However, interpreting this description as a permit for the unrestricted and unscrupulous exploitation of nature is entirely wrong. Understanding this description correctly will depend precisely on having the correct depiction of God. The earth is not the property of man, but the garden of God, in which man is not an arbitrary ruler, but a representative of the Creator, and must give an account for it..$^{29}$ If this »having dominion «, »tilling « and »keeping " is seen in the context of the Old Testament idea of a king who is a ruler but also a shepherd, with the quality of his rule being measured by the prosperity of his subjects, then the unjustifiable allegation of »ecological sin « directed towards the Judeo-Christian tradition will be clearly visible.

There is no doubt that the distorted image of the Creator is undoubtedly one of the deep roots of the modern ecological crisis. Hence, the correction of this image which Jesus makes in the Sermon on the Mount will be of fundamental importance for Christian ecological spirituality. As mentioned above, the relationship to the Father in heaven is a reference point for the whole Sermon on the Mount, and it is also a central part of the precisely shaped literary structure of the first of the five talks of Jesus, which make up the Gospel of Matthew. As Ulrich Luz emphasizes, at the center of the Sermon on the Mount is the prayer »Our Father«, which indicates the fundamental importance of relating every-

\footnotetext{
${ }^{29}$ J. Richard MIDDLETON, The Liberating Image. The Imago Dei in Genesis 1, Grand Rapids, MI, Brazos, 2005, 204.
} 
thing to the Father in heaven. ${ }^{30}$ The word pater appears in the Sermon on the Mount explicitly as many as fourteen times, however, other numerous passages must be taken into account in which the form of so-called passivum divinum is used. If Jesus e.g. declares in blessings that the sad will be comforted, the silent will possess the land, and the poor in spirit will be given the kingdom of heaven (Matt 5:3-10), He relates not simply to the natural consequences that will appear automatically as a result of human actions, but he foreshadows a free and undeserved gift of God. The figure of the Father, and this in the unique sense in which Jesus uses the word ${ }^{31}$, is, therefore, something like a golden thread, which is woven through the entire structure of the Sermon on the Mount.

It is worth paying attention to the fact that the mention of the Father in the Sermon on the Mount is almost always associated with the addition »in heaven«. This characteristic motif is important just for the revision of the image of God. On the one hand, Jesus characterizes the Father very clearly as someone close to every human person. He is someone who looks into the heart and appreciates what is humble and hidden from other people's eyes (Matt 6:1-17), who is merciful to everyone (Matt 5:46-47), gives willingly what is good to those who ask Him (Matt 5:7-11), but also demands a merciful attitude from everyone (Matt 6:14-15). On the other hand, the indication that the Father is »in heaven « is a warning not to create anthropomorphic images of God too hastily. The proximity of God cannot be the basis for a too simplistic depiction of Him. The Father is »in heaven « and thus transcends human imagination and eludes human thinking patterns. ${ }^{32}$ If a distorted depiction of God is connected with a blind faith in progress and with an irrepressible desire to possess, then the result is a destructive attitude towards the surrounding world and all its consequences seen in the ecological crisis.

Instead of worrying, as Jesus said, one should seek the Kingdom of God and its righteousness (Matt 6:33), trusting that daily needs will be met without this obsessive concern. To seek the Kingdom of God and its righteousness is to seek to live according to the new consciousness of being God's child, to look for the signs of His presence and action, and to gain more and more a new »look«, a new way of seeing and assessing reality. It also means perceiving oneself in the broad context of God's plan, and hence the whole of creation. When Jesus tells to seek the Kingdom of God and his righteousness, he does not intend to distract man from reality and direct his attention to the afterlife. Rather, it is a call to seek the true shape of the world in harmony with the original intention of the Creator. ${ }^{33}$ The righteous attitude of man leads to that which Jesus in

\footnotetext{
${ }^{30}$ Luz, Matthew 1-7..., 309-310; Lohfink, Wem gilt die Bergpredigt..., 133-138.

${ }^{31}$ Cf. Luz, Matthew 1-7..., 314-316.

${ }^{32}$ Luz, Matthew 1-7..., 316.

${ }^{33}$ Strecker, The Sermon on the Mount..., 139-140.
} 
the Sermon on the Mount describes as righteousness. ${ }^{34}$ The reign of God will achieve its final completion at the end of history, but it seems that identifying heaven only with an outside world, won't correspond to Jesus' intention. The Kingdom of Heaven begins now, at the very center of this reality entrusted to man. This can be done precisely when one takes the attitude, which Jesus defines as righteousness. In the Sermon on the Mount the concept goes beyond the meaning of today's justice. It means rather the attitude best summed up by the set of Jesus' eight blessings. ${ }^{35}$ The blessings, which can also be interpreted as a presentation of the attitude of Jesus Himself, sketch the profile of a person devoted to God and living according to God's will. The building of a new way of treating the environment begins with the decisions of individual people, but of course, it is going to transform the whole of reality. This can only be done by the joint effort of many.

Here we touch one more important element of the new image of God, shown by Jesus in the Sermon on the Mount, which will be important for ecological spirituality. It is visible at the very beginning of the Lord's Prayer. The disciples are invited to address the Father with the words »our Father«: »our«, and not merely »my« ${ }^{36}$ The communal aspect, one might even say, the social aspect, is crucial for proper Christian spirituality. Christian faith is always based on a personal choice for Jesus Christ, but despite its very personal dimension, it is not only a private matter. The Christians are sent to the community, which, on the one hand, is to support their faith, and on the other hand, remains the place where the practical love of neighbor is realized. The community is also a place of engagement in social life, and therefore also in the protection of the common good of the natural environment.

It is this community aspect that opens up the prospect of engagement in shaping economic structures and market mechanisms. The environmental disaster is not merely the result of the abuse of an in itself good system, but it raises the question of the relevance and fairness of the current economic structures. The commentaries to the above analyzed parts of the Sermon on the Mount sometimes point to the flaws of the capitalist system, built upon the assumption that the best economy is based on personal freedom, in which everyone cares about their own interests first. ${ }^{37}$ This criticism is undoubtedly justified. However, it is rarely pointed out that the historical alternative in the form of socialist systems based on state ownership has led to an even greater catastrophe. Its effect was not any greater attention to the environment, as they not only suspended private ownership, but also suppressed personal responsibility. One seems to be clear: there will be no effective protection of natural

\footnotetext{
${ }^{34}$ Cf. Benno PRZYBYLSKI, Righteousness in Matthew and his World of Thought, Cambridge, Cambridge University Press, 1980, 1-2.

${ }^{35}$ Patte, The Gospel According to Matthew..., 75-76.

${ }^{36}$ Vaught, Sermon on the Mount..., 128.

${ }^{37}$ Hauerwas, Matthew..., 81.
} 
resources without an effective change in ways of production and consumption of goods and so in the way of living. However, this change will only be possible if individual people begin to change their lifestyle, mastering the desire to possess and excessive consumption. An essential element in this process from a Christian point of view is the new spiritual sensitivity, which can be described precisely as ecological spirituality.

\section{Conclusion}

The diagnosis of the human condition carried out by Jesus in the Sermon on the Mount turns out to be extremely topical in the context of the contemporary ecological crisis and the question of how an adequate ecological spirituality should look like. An amalgam of the unlimited desire to possess and fear for the future produce a particular attitude, and the dissemination and consolidation in the common mentality engender economic structures that lead to environmental devastation. In calling for a revision of the way of looking at the world, to be able to see not only its beauty but also to whom this beauty points - the Father in heaven, Jesus invites a renewed look at reality. The environmental disaster is not merely caused by the increase in the number of people, by technical progress or by economic processes themselves, although the latter are indeed fragile and need to be reformed. The key is the ability to keep a distance from the goods that pass away. It is not for nothing that among the four virtues, which since Plato's time have been considered crucial in human life, and which since the time of St. Ambrose have been called cardinal virtues, a prominent place is occupied by the virtue of moderation. According to ancient thinkers, moderation forms the foundation of any other human virtue. Of course, it would be wrong to project these reflections into the words of Jesus in the Sermon on the Mount, but it seems that this ancient intuition corresponds to what Jesus expressed as "poverty in spirit«, as »not serving mammon « and as »not caring too much." It turns out that the Sermon on the Mount contains a powerful impulse that can become a source of spiritual motivation to »strengthen the passion for caring for the world «. ${ }^{38}$

${ }^{38}$ LS 216. 


\section{Marian Machinek*}

Ima li Govor na gori ekološku poruku? Doprinos ekološkoj duhovnosti

\section{Sažetak}

Svrha ovoga članka je ispitivanje može li Govor na gori (Mt 5-7) biti inspiracija za ekološku duhovnost. Isusova dijagnoza ljudskog stava (Mt 6,19-34), obilježena neskromnom željom za posjedovanjem i pretjeranom zabrinutošću za budućnost, ni danas nije izgubila ništa u svojoj istinitosti. Promjenu ovog stava omogućio bi obnovljen pogled na okolnu prirodu. Odnos prema Bogu bit će time ključan element kršćanske ekološke duhovnosti.

Ključne riječi: antropocentrizam, egzistencijalna tjeskoba, ekologija, ekološka duhovnost, Evandelje po Mateju, Govor na gori, Otac na nebu, želja za posjedovanjem.

\footnotetext{
* Prof. dr. sc. Marian Machinek, Varmijsko i mazurijsko sveučilište u Olsztynu, Teološki fakultet, Ul. Hozjusza 15, PL-11-041 Olsztyn, Poljska.
} 